\title{
PROTECTIVE BEHAVIOR OF TEACHERS OF A SPECIAL SCHOOL AS A PSYCHOLOGICAL PROBLEM
}

\section{Pohribna Alona ${ }^{1}$}

\section{DOI: https://doi.org/10.30525/978-9934-571-89-3_43}

In the conditions of reforming the system of special education and the transition to inclusion, which is observed recently in Ukraine, special attention should be paid to the personality of the teacher of a special school. After all, the teacher needs to combine pedagogical influences with psychological and medical ones; to provide a correctional and developmental orientation of the educational process; to form a unified security and pedagogical regime at school and within the family, etc., which requires him to improve himself constantly, to develop both his professional and personal qualities. Considering the fact that their professional activities are stressful in nature, the problem of the psychological health of teachers in this category acquires special significance.

An important indicator of the psychological well-being of the individuals is the level of their socio-psychological adaptation. In our research, we focused on the study of the protective behavior of teachers of a special school, because it is, in the opinion of many scientists (V.O. Ananiev, F.V. Bassin, M.A. Havrylenko, R.M. Hranovska, L.R. Hrebennikov, B.V. Zeiharnyk, E.I. Kyrshbaum, H.S. Korytova, I.Ya. Kotsan, V.K. Miaher, A.A. Nalchadzhian, I.M. Nikolska, O.T. Sokolova, M.V. Yurkova and others), a part of the general adaptive system of the individual, which protects it from psycho-traumatic experiences, eliminates anxiety and helps maintain self-esteem in a situation of motivational conflict $[1$, p. 78-86; 2, p. 114; 3, p. 17-20; 4, p. 80-135, 189-200].

The methodological basis of our research was the psycho-evolutionary theory of emotions R. Plutchik and the structural theory of personality H. Kelierman, according to which protective mechanisms are derived from emotions (joy, fear, sadness, anger, anticipation, astonishment, disgust, acceptance). The last mentioned, in turn, are defined as the main facilities of adaptation, which purpose is to solve the problem of survival at all phylogenetic levels. In order to cope with basic emotions, eight basic defense mechanisms are formed, the manifestations of which depend on the age development and characteristics of cognitive processes. In general, they form a hypothetical scale of maturity - primitiveness of the defense mechanisms, which with the maturity growing can be represented as follows: denial, regression, projection, substitution, repression, reactive formations, intellectualization, compensation. Psychological protection, thus, is considered by the authors as a consistent distortion of the cognitive and affective components of the image of the real exclusive situation in order to alleviate emotional stress [6, p. 3-33].

Using the psychodiagnostic method "Index of life style" (IHC) R. Plutchik, H. Kelierman, H.R. Conte, in the adaptation of L.I. Wasserman, O.F. Yerysheva et

\footnotetext{
${ }^{1}$ Donbass State Pedagogical University, Ukraine
} 
al., it was found that the leading mechanism of psychological protection within teachers of special boarding schools for children with intellectual disabilities is projection $-71,3 \%$. We should add, that for the analysis of the dominant defense mechanisms, we used only mechanisms with a high level of intensity (high intension) that have diagnostic value for us (Figure 1).

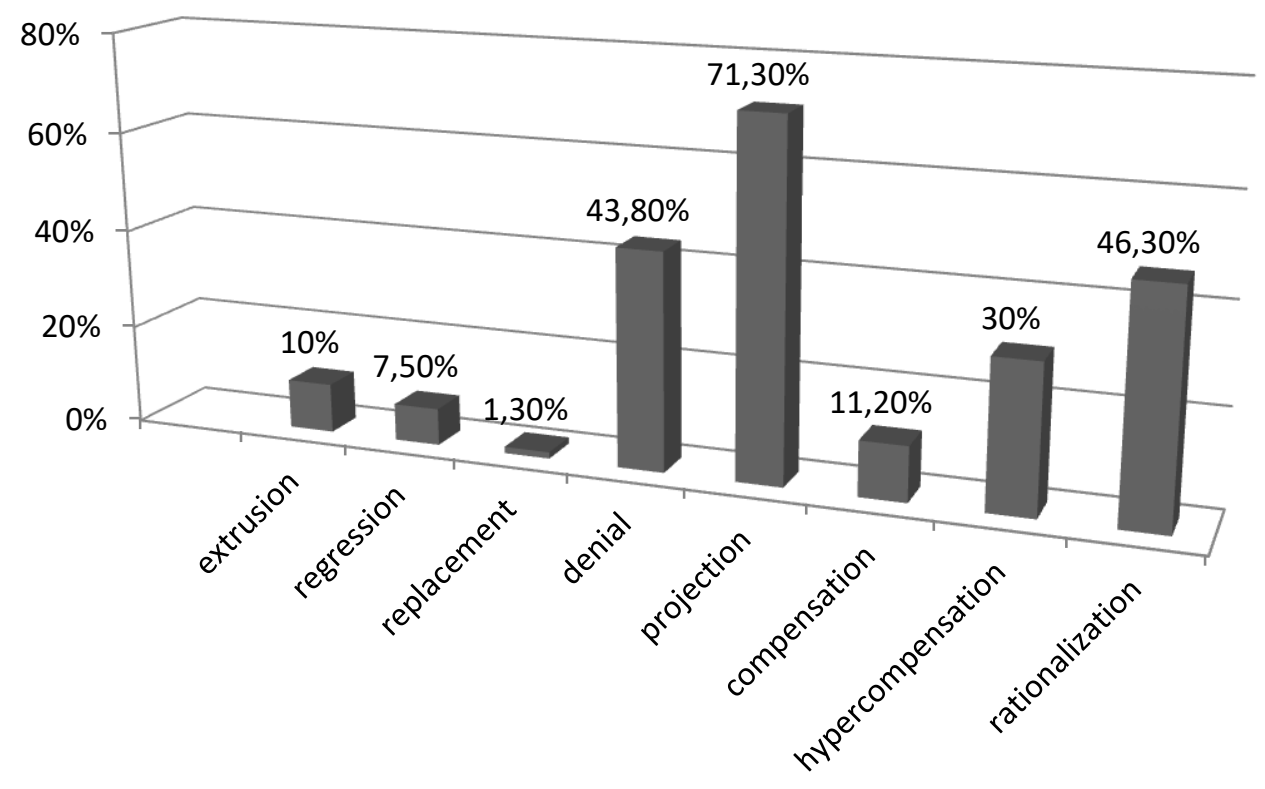

Figure 1. Representation of protective mechanisms within teachers of special boarding schools for children with intellectual disabilities

So, the majority of teachers in these educational institutions use a primitive, immature protection mechanism, as an option of eliminating stressful experiences, which, according to R. Plutchik, H.R. Conte, is a projection. The high degree of expression of this protective mechanism indicates the tendency of this category of teachers to transfer unconscious and unacceptable for their personality feelings, thoughts, motives of behavior to other people. At the same time, there is a lack of criticism towards their own imperfections, a tendency to blame others for their own problems, which can lead to an erroneous interpretation of reality. Teachers fixed the following manifestations of projection in themselves: they are irritated by people who dominate others, treat them unkindly or selfishly, gossip, achieve goals at any cost ("go over their heads"); they are repelled by hypocritical deceitful people who are trying to be constantly in the spotlight or people, who they can't rely on. It should be noted that the basic emotion in the projection is rejection. Consequently, not accepting any side of their personality, teachers interfere with the transference, that intensifies the criticism of the surrounding reality and the nearest social environment. A negative consequence of such protection is the desire to correct an external object onto which their own unacceptable feelings, desires, etc. are projected. The nature of pedagogical activity allows us to use pupils as an object for such a transfer and, thus, 
to prevent the loss of self-esteem and to justify their own negative manifestations towards others.

It has to be noticed, that a comparative analysis of the results, obtained from teachers of general education schools of different types, allowed us to state the following: the number of teachers in special boarding schools for children with intellectual disabilities with registered indicators of this protection mechanism at a statistically significant level exceeds the representation of indicators obtained from other categories of teachers: $71,3 \%$ of teachers of special boarding schools for children with intellectual disabilities significantly exceed $48,7 \%$ of teachers from general educational boarding schools $(\mathrm{p} \leq 0,01)$ and $52,5 \%$ of teachers in secondary schools $(\mathrm{p} \leq 0,05)$.

It should be noted, that the projection as the leading mechanism of psychological protection within teachers of special boarding schools for children with intellectual disabilities turned out to be a maladaptive form of psychological protection for this group of specialists $(r=0,28 ; p \leq 0,05)$. This gave us the reason to assume that the actualization of the specified unproductive protective mechanism indicated for the given pedagogical environment causes the emergence and manifestations of emotional burnout among specialists.

Using the methods of mathematical statistics, it was found that the projection is statistically more appropriate for teachers of special boarding schools for children with intellectual disabilities who have signs of emotional burnout $(\mathrm{p} \leq 0,05)$. It also found moderate positive relationships with burnout phases such as resistance $(\mathrm{r}=0,34 ; \mathrm{p} \leq 0,01)$ and depletion $(\mathrm{r}=0,39 ; \mathrm{p} \leq 0,001)$. Moderate positive relations with the symptoms of the exhaustion phase by "depersonalization" ( $r=0,47$; $p \leq 0,001)$, "psychosomatic and psycho-vegetative disorders" $(r=0,48 ; p \leq 0,001)$ and the phase of resistance - "reduction of professional duties" $(r=0,31 ; p \leq 0,01)$ were recorded.

On the strength of the above, it can be concluded that the high representation of the projection in the repertoire of protective behavior is directly proportional to the vulnerability of teachers of special boarding schools for children with intellectual disabilities to the appearance of signs of emotional burnout. This mechanism of psychological protection largely determines the deformation (dehumanization) of relations with the subjects of professional interaction, who starts to be perceived as the objects for manipulation and do not cause any emotional response; the emergence of destructive changes in the emotional-volitional and personal spheres of specialists, in the system of professional values of the individual; leads to psychosomatic and psycho-vegetative disorders, which in turn cause all sorts of dysfunctions and worsen of the quality of life of a specialist.

Further prospects are the study of adaptive forms of protective behavior, which, in our opinion, have a preventive effect on the occurrence of emotional burnout in this educational environment. 


\section{References:}

1. Bassin F.V., Burlakova M.K., Volkov V.N. (1988). Problema psikhologicheskoy zashchity [The problem of psychological defense]. Psychological journal, no. 3, pp. 78-86.

2. Granovskaya R.M. (2010). Psikhologicheskaya zashchita [Psychological defense]. St. Petersburg: Speech. (in Russian)

3. Kirshbaum E.I., Eremeeva A.I. (2000). Psikhologicheskaya zashchita [Psychological defense]. Moscow: Meaning. (in Russian)

4. Korytova G.S. (2006). Zashchitnoe i sovladayushchee povedenie lichnosti: teoreticheskie osnovaniya [Protective and coping behavior of a person: theoretical grounds]. Ulan-Ude: Publishing House of Buryat. un-ta. (in Russian)

5. Pohribna A.O. (2016). Osoblyvosti zakhysno-opanujuchoji povedinky vchyteliv specialjnykh zaghaljnoosvitnikh shkil-internativ dlja ditej iz vadamy intelektu [Features of protective-coping behavior of teachers of special general education boarding schools for children with intellectual disabilities]. Pedagogy and psychology of vocational education, no. 2, pp. 105-114.

6. R. Plutchik, H. Kelierman (1980). A general psychoevolutionary theory of emotions. Emotion: Theory, research, and experience: Vol. 1. Theories of emotion. NY.: Academic Press, pp. 3-33. 